\title{
MARAKNYA HUBUNGAN SEKSUAL ATAU PRA SEKS REMAJA SEKARANG INI AKIBAT PERKEMBANGAN TEKNOLOGI YANG SEMAKIN CANGGIH
}

\begin{tabular}{|c|}
\hline Jaimah \\
\hline $1910128120016 @$ mhs.ulm.ac.id \\
Program Studi Pendidikan IPS FKIP, Universitas Lambung Mangkurat \\
\hline
\end{tabular}

\begin{abstract}
ABSTRAK
Seiring dengan perkembangan zaman yang semakin canggih, membuat kebabasan dan dengan mudahnya akses informasi atau situs-situs yang terbuka menjadikan pengaruh budaya barat dengan cepatnya masuk mempengaruhi pikiran kotor para remaja, sehingga banyak sekali remaja yang suka meniru budaya-budaya luar yang masuk. Sangat banyak informasi-informasi dari media sosial ataupun media massa, media elektronik, bahkan media cetak yang menampilkan secara langsung tanpa privat akan sebuah hal yang tidak mendidik sama sekali bahkan menyesatkan. Berbagai hal tersebut dapat mempengaruhi serta mendorong sebuah perilaku seksual atau hubungan terlarang. Situs-situs pornografi sangat mempengaruhi dan dapat membawa para remaja ke arah yang negatif, sehingga berbagai dampak-dampak yang ditimbulkan..
\end{abstract}

\section{Kata kunci : Remaja, Seksual, dan Media}

\section{PENDAHULUAN}

Era globalisasi sekarang ini yang mana sebuah perkembangan alat teknologi semakin maju dan semakin canggih yang kini kiat berkembang pesat hampir diseluruh penjuru dunia dan masuk kekalangan masyarakat-masyarkat baik diperkotaan maupun diperdesaan. Tidak dapat dihindari bahwa hadirnya alat teknologi tersebut yang membuat informasi semakin mudah dan nyaman untuk ditelusuri atau disebut dengan internet. Hadirnya internet atau media sosial juga sangat dibutuhkan orang sebagai alat untuk kegiatan sehari-hari, baik dari segi pendidikan, berbisnis, berinteraksi antara satu dengan yang lainnya atau sebagai alat komunikasi serta keperluan lainnya. Media sosial berpengaruh besar bagi yang salah menggunakannya didalam sebuah kehidupan, baik pengaruh positif maupun pengaruh negatif bagi masyarakat khususnya di kalangan remaja. Media sosial dan situs-situs pornografi sudah tidak bisa dihindari lagi bagi 
kalangan remaja saat ini, justru teknologi atau bisa disebut dengan media sosial sekarang ini telah menjadikan sebuah alat kegemaran dan alat bikin kesenangan sehingga membuat para pengguna ingin setiap hari menggunakan media sosial tersebut. Anak remaja sekarang ini lebih bergantung kepada internet, anak remaja juga sangat menyukai sekali media sosial, mereka menggunakan handphone terkadang sampai full seharian dan bahkan malam juga, banyak dari mereka yang juga menggunakan jam tidurnya untuk bermain handphone tersebut. Mereka berkelana disitus internet tiada henti, dan itu dilakukan secara terus-menerus dari hari kehari.

Masa remaja merupakan suatu proses tumbuh dan berkembangnya seorang individu dari masa kecil atau kanak-kanak ke dewasa muda atau bisa disebut dengan remaja. Pada masa remaja termasuk kedalam konteks yang sangat rentan mengenai sebuah pengaruh hal-hal baru, khusunya bagi para remaja yang tidak bisa mencegah terpengaruhnya hal-hal yang berbau negatif tersebut. Anak remaja sekarang ini lebih mengarah sekali dan lebih gampang untuk melakukan adaptasi dengan perkembangan zaman baik dari segi berbagai arus dunia maya, pada akhirnya menyebabkan perilakuperilaku menyimpang yang diakibatkan masuknya budaya dari luar melalui berbagai arus globalisasi ataupun arus informasi yang bisa diakses kapan saja dan dimanapun.. Hubungan terlarang yang dilakukan para remaja merupakan sebuah perbuatan yang sangat berisiko kepada permasalahan kesehatan kelamin atau alat reproduksi pelaku. Perbuatan menyimpang tersebut akan menjadikan beberapa akibat atau dampak negatif terhadap diri pelaku seperti terjadi permasalahan penyakit menular yaitu HIV/AIDS dan juga akan terjadi hal-hal yang tidak diduga ataupun tidak diinginkan, seperti terjadinya kehamilan. Hamil muda diluar nikah akan berdampak sosial seperti putus sekolah ataupun diiringi dengan pikiran yang stress, kanker, infertilitas/kemandulan.

Aspek-aspek yang berpengaruh terhadap sebuah perbuatan menyimpang atau seks bebas yaitu berasal dari informasi yang mereka dapat atau dari media sosial, bisa juga berasal dari pengaruh teman, baik dari teman sekolah maupun pengaruh masyarakat seperti pergaulan-pergaulan yang melebihi batas. Sekarang perkembangan serta kemajuan dari teknologi media massa semakin melonjak dan berkembang pesat. Bukti dari kemajuan teknologi semkain melonjak dan berkembang pesat kita bisa lihat dan rasakan sendiri bahwa semakin mudahnya kita menelusuri atau mengakses banyak informasi-informasi atau situs-situs lainnya seperti situs-situs pornografi. Melalui media 
massa sangat banyak terdapat berbagai informasi, tidak hanya media massa tetapi media elektronik maupun media cetak pun juga sama. Sekarang ini sangat marak denga sebuah situs-situs pornografi yang berdampak negatif dan bisa mempengaruhi para remaja. Situs-situs porno tersbut sangat tidak wajar untuk ditonton anak yang dibawah umur karena sangat mempengaruhi dan merusak perkembangan kepribadian bagi para remaja, dan juga akan membuat remaja cenderung ingin melakukannya atau memprakekkannya sehingga membuat ingin terus menerus melakukan atau disebut dengan ketagihan yang sangat serius, tetapi juga pergeseran pada emosi dan perilaku sosial.

\section{TUJUAN}

Tujuan dari artikel ini adalah untuk mengetahui seberapa berpengaruhnya perkembangan teknologi sekarang ini terhadap masa remaja.

\section{METODE}

Pembuatan artikel ini menggunakan metode studi literatur. Data yang diperoleh bersumber dari situs internet seperti karya-karya ilmiah atau jurnal dari google scholar yang dianggap relevan dan sesuai dengan artikel yang dibuat.

\section{HASIL PEMBAHASAN}

Media massa atau alat komunikasi tidak selalu berdampak positif tetapi juga sangat berdampak negatif bagi para penggunanya, media massa akan berdampak positif jika digunakan dengan baik dan benar, tetapi media massa akan berdampak negatif jika disalah gunakan. Sangat banyak sekali akibat yang muncul dari terknologi media massa atau media komunikasi tersebut, satu diantaranya yaitu media komunikasi yang hampir setiap individu memilikinya yaitu handphone. Pengguna internet sekarang ini tidak hanya digunakan sebatas melakukan interaksi misalnya masalah bisnis, pendidikan dan lain sebagainya, akan tetapi digunakan sebagai alat berinteraksi antarsesama lainnya. Kini media massa menghadirkan berbagai aplikasi-aplikasi yang membuat jauh jadi terasa dekat, contonya seperti facebook, instagram, dan aplikasi sejenis lainnya, yang mana didalam aplikasi tersebut kita sangat mudah untuk mencari teman dari berbagai daerah karena bersifat publik. Sehingga pada akhirnya dua jenis yang berbeda memiliki sebuah hubungan yang lebih dari sekedar teman tetapi lebih dekat lagi. Tidak dapat 
dihindari bahwa hadirnya alat teknologi tersebut yang membuat informasi semakin mudah dan nyaman untuk ditelusuri atau disebut dengan internet. Hadirnya internet atau media sosial juga sangat dibutuhkan orang sebagai alat untuk kegiatan sehari-hari, baik dari segi pendidikan, berbisnis, berinteraksi antara satu dengan yang lainnya atau sebagai alat komunikasi serta keperluan lainnya. Disamping dari dampak positifnya media komunikasi, adapun dampak negatifnya juga seperti sering terjadi berbagai penipuan-penipuan, situs dan video-video pornogragi dan juga akan bisa menjadikan orang candu melakukan tindakan kejahatan seperti yang sering kita temui di mediamedia sosial yaitu bullying, saling sindir-sindiran melalui kata-kata dan akhirnya terjadilah hal-hal yang tidak diduga..

Remaja saat ini menjadikan media sosial sebagai ajang untuk mencari informasi dan berhubungan dengan orang-orang baru hingga sampai pencarian jodoh, ada beberapa aplikasi yang sering sekali digunakan orang-orang dalam pencarian jodoh. Contohnya seperti aplikasi tantan, tider dan aplikasi sejenis lainnya. Anak remaja sangat suka mendekatkan diri dengan teman yang sebelumnya belum pernah dikenal, dan mereka ketemu hanya melalui media massa tersebut, sehingga menyebabkan sebuah pertemuan dan lain sebagainya. Kemudian dengan seiring berjalannya waktu yang diakibatkan karena pertemuan, maka mereka akan sering melakukan jalan berdua, nongkrong dan lama kelamaan akan mengarah ke hal-hal yang negatif diawali dengan hal yang mendasar terlebih dahulu seperti pegangan tangan, pelukan, ciuman, merabaraba hal sensitif, onani dan sampailah ke hubungan yang terlarang yaitu seks bebas.

Situs Pornografi merupakan sebuah video yang bertujuan untuk membuat sesorang yang menonton menjadi terangsang nafsunya, sehingga menyebabkan seseorang yang menonton video pornografi tersebut akan melakukan onani sendiri atau mereka yang tidak dapat menahan nafsunya lagi akan melakukan hubungan seks dengan pacar atau orang yang dekat dengannya. Munculnya media massa yang memiliki fasilitas situs-situs pornografi justru menjadi faktor pendukung terjadinya perbuatanperbuatan menyimpang atau hal yang tidak wajar untuk dilakukan khusunya bagi anak remaja yang masih dibawah umur. Banyak sekali remaja yang kurang luas pengetahuannya dan kurang taunya tentang informasi mengenai kesehatan alat reproduksi, sehingga mereka menganggap hal sepele tentang perilaku seksual atau seks bebas. 
Sangat banyak informasi-informasi dari media sosial ataupun media massa, media elektronik, bahkan media cetak yang menampilkan secara langsung tanpa privat akan sebuah hal yang tidak mendidik sama sekali bahkan menyesatkan dan cenderung membuat terjadinyya perilaku menyimpang. Berbagai hal tersebut dapat mempengaruhi serta mendorong sebuah perilaku seksual atau hubungan terlarang. Situs-situs pornografi sangat mempengaruhi dan dapat membawa para remaja ke arah yang negatif, sehingga berbagai dampak-dampak yang ditimbulkan. Situs-situs porno tersbut sangat tidak wajar untuk ditonton anak yang dibawah umur karena sangat mempengaruhi dan merusak perkembangan kepribadian bagi para remaja, dan juga akan membuat remaja cenderung ingin melakukannya atau mempraktekkannya sehingga membuat ingin terus menerus melakukan atau disebut dengan ketagihan atau kecanduan yang sangat serius.

Seperti yang sudah dijelaskan diatas bahwa hubungan terlarang yang dilakukan para remaja merupakan sebuah perbuatan yang sangat berisiko kepada permasalahan kesehatan kelamin atau alat reproduksi pelaku. Perbuatan menyimpang tersebut akan menjadikan beberapa akibat atau dampak negatif terhadap diri pelaku seperti terjadi permasalahan penyakit menular yaitu HIV/AIDS dan juga akan terjadi hal-hal yang tidak diduga ataupun tidak diinginkan, seperti terjadinya kehamilan. Hamil muda diluar nikah akan berdampak negatif yang sangat banyak seperti malu yang dirasakan pihak keluarga kepada para masyarakat atas perbuatan anak tersebut yang tidak senonoh, serta juga bisa menyebabkan putus sekolah ataupun diiringi dengan pikiran yang stress, kanker, infertilitas/kemandulan.

\section{SIMPULAN}

Hadirnya internet atau media sosial juga sangat dibutuhkan orang sebagai alat untuk kegiatan sehari-hari, baik dari segi pendidikan, berbisnis, berinteraksi antara satu dengan yang lainnya atau sebagai alat komunikasi serta keperluan lainnya. Media sosial berpengaruh besar bagi yang salah menggunakannya didalam sebuah kehidupan, baik pengaruh positif maupun pengaruh negatif bagi masyarakat khususnya di kalangan remaja. Media sosial dan situs-situs pornografi sudah tidak bisa dihindari lagi bagi kalangan remaja saat ini, justru teknologi atau bisa disebut dengan alat komunikasi media sosial sekarang ini telah menjadikan sebuah alat kegemaran dan alat bikin kesenangan sehingga membuat para pengguna ingin setiap hari menggunakan media 
sosial tersebut. Anak remaja sekarang ini lebih bergantung kepada internet, anak remaja juga sangat menyukai sekali media sosial, mereka menggunakan handphone terkadang sampai full seharian dan bahkan malam juga, banyak dari mereka yang juga menggunakan jam tidurnya untuk bermain handphone tersebut. Mereka berkelana disitus internet tiada henti, dan itu dilakukan secara terus-menerus dari hari kehari.

\section{DAFTAR PUSTAKA}

Hasanah, M., \& Saidillah, M. (2020). PENGARUH PEMANFAATAN MEDIA SOSIAL DAN PENGETAHUAN KEWIRAUSAHAAN PADA MINAT WIRAUSAHA MAHASISWA. CENDEKIA: Jurnal Pendidikan dan Pengajaran, 4(2), 106.

Hasugian, B. S. (2018). Pengaruh Media Sosial Terhadap Perilaku Remaja Millenial. Network Media, 1(1).

Kuswandi, K., Ismiyati, I., \& Rumiatun, D. (2019). ANALISIS KUALITATIF PRILAKU SEKS BEBAS PADA REMAJA DI KABUPATEN LEBAK. JPP (Jurnal Kesehatan Poltekkes Palembang), 14(1), 18-24.

Lestari, A. Y., \& Kusmiyati, Y. (2015). Hubungan intensitas mengakses situs porno dengan perilaku seksual pranikah remaja. Jurnal Kesehatan Ibu dan Anak, 7(1), $5-9$.

Nurjanah, S. (2014). Pengaruh Penggunaan Media Sosial Facebook terhadap Perilaku Cyberbullying pada Siswa SMAN 12 Pekan Baru. Jom FISIP , 1 (2), 2.

Primasti, D., \& Dewi, S. I. (2018). Pengaruh Media Sosial Terhadap Penyimpangan Perilaku Remaja (Cyberbullying). Reformasi, 7(2). 